\title{
The Federal Program of Payment for Hydrological Environmental Services as an Alternative Instrument for Integrated Water Resources Management in Mexico City
}

\author{
María Perevochtchikova* and Adrián Vázquez Beltrán
}

\author{
Center for Demographic, Urban and Environmental Studies, El Colegio de México A.C., México
}

\begin{abstract}
This paper discusses the possibility of considering the federal program of Payment for Hydrological Environmental Services, implemented by the National Forest Commission in Mexico since 2003, as an alternative instrument of the environmental public policy in order to contribute to the Integrated Water Resources Management, based on the territorial concept of basin. As a case study we present Mexico City, which is the most important urban area of the country that faces serious problems in providing water to its population. The used methodology consists of cabinet work with the analysis of scientific papers, data bases, public material, and the field work with the application of proof structured interviews and one questionnaire to the principal groups of participants (authorities and communities). In the final part we compare the points of view of these actors and review the idea of the viability through a combination of two theoretical concepts into the application of one environmental policy program.
\end{abstract}

Keywords: Conservation Land, integrated water resources management, hydrological environmental services, Mexico City, public policy.

\section{INTRODUCTION}

The fact of environmental degradation caused by the irresponsible use of natural resources was first internationally recognized in the 1970s which opened a path to the creation of new methodological concepts of environmental public policies aimed at bringing to life postulates of Sustainable Development. This concept searches the balance among objectives of economic progress, social well-being and biophysical functioning of ecosystems, that provide environmental services to the people, and that is based on technological and scientific development with an integrated interdisciplinary analysis at large scale [1-4].

Within the topic of water, during the 1992 Conference on Water and Environment and the United Nations Conference on Environment and Development, the concept of management of river basins has been implemented worldwide within the conceptual framework of Integrated Water Resource Management (IWRM). This concept regards catchment basins and sub-basins as planning units that integrate all the ecosystems that regulate the hydrological cycle. Water here is considered as the fundamental link between human development and nature, in terms of the complex interrelationship among the physical factors that form part of the cycle (air-water-soil) with all the biodiversity that it supports, including the society that influences change in this cycle. Unfortunately, although this focus is positive in its intention of conserving the environment, it has come up against many limitations when put into practice [5]; often its only trace is to be found in

*Address correspondence to this author at the Camino al Ajusco, 20, Col. Pedregal de Santa Teresa, Del. Tlalpan, CP 10740, D.F., México; Tel: +5255-54493000, Ext. 4065; E-mail: mperevochtchikova@colmex.mx development plans and similar documents. Most of the limitations have to do with the specific political, administrative, cultural and even educational factors of each country, above all in the developing world.

In Mexico, despite many attempts, it has been impossible to adopt the approach of IWRM to the real practice, due to several limitations, such as: i) lack of political coordination in territorial planning; ii) weak cooperation between and within institutions, society, government and scientists; iii) negligible public participation in decision-making; iv) weak environmental legislation; v) lack of reliable information on which to base public policies, as well as vi) weak public education system within the country, with its lowest level in the rural zones $[1,6]$.

The special importance of incorporating the IWRM focus in Mexico retakes in virtue that it forms part of one of the 17 mega-diversity countries; with almost $12 \%$ of existing species of flora and fauna of the world. Particularly, according to the National Forest and Land Inventory 2004$2009,33 \%$ of the territory is covered by forest and jungle; $29 \%$ by Xerophyte thicket and $8.2 \%$ by other forest areas that have direct link with water resources [7]. This resource has very heterogeneous space distribution in the country that relies on the peculiarities of the regional climate conditions (temperature and precipitation). On the other hand, it is very important to comment that the forests' presence coincides with the location of the highest territory's parts, the lowest population density, the highest marginal index, the living place of indigenous peoples, and the $70 \%$ of ejidal and community land ownership [8-10].

Actually the forestry sector in Mexico faces many problems and the biggest of them is related to deforestation, degradation and, consequently, loss of forest ecosystems. The actual deforestation rate is from 200 thousand to 1.5 
million ha per year [11]. So the main causes of the continuous deforestation in Mexico are detected: I) the change in land use; II) the illegal forest felling and overexploitation of the forest resources; III) the plagues and diseases of the vegetation; and IV) forest fires.

But it should not be forgotten that forests provide not only wood products (the goods), but many environmental services too. Which include supply, regulation and cultural services, such as carbon capture, preservation of hydrological cycle, conservation of biodiversity and landscape; and substantial services that are necessary to support the other all [12]. The conservation of these services results very important in the context of continuous environmental impact produced by human activities that modify the complete water cycle, in particular characteristics as precipitation, soil moisture, runoff and evaporation. This situation translates in the generation of new and more extreme climate conditions (clearer in detecting on regional and local scale), with more intensive and shorter rainfalls in some territories, prolonged scarcities in others parts, loss of water quality, with its subsequent impact on public health and infrastructure problems [13].

In this sense it is indispensable to incorporate the ecosystem approach in water management, complemented by official actions and policies and programs with alternative conservation activities, such as reforestation programs, ecological territory planning, or other compensation schemes dedicated to the ecosystem preservation. For example, the payment mechanisms for forest hydrological environmental services could be considered as an alternative instrument, because it is based on the principles of environmental, economic and social justice within the territory planning unit of the catchments. In this scheme the users of environmental services compensate the landowners of the highest parts of the rivers basins for the realization of different activities for the conservation of vegetation and soil condition that improve the water trapment capacity [14-19].

Because of this, in the present study, we have tried to integrate two theoretical concepts of Integrated Water Resource Management and of Environmental Services to discuss the possibility of considering the Mexican federal program of Payment for Hydrological Environmental Services (PHES), implemented and operated by the National Forest Commission since 2003, as an alternative instrument of the environmental public policy in order to contribute to the principles of IWRM, both based on the territorial unit of basin. As a case study we look at Mexico City, situated within the Valley of Mexico that is the most important urban area of the country that faces serious problems in providing water in sufficient quantity and quality to its population.

\section{THEORETICAL FRAME}

The theoretical concept of IWRM was internationally consolidated in the early 1990 s after several international agreements were signed [20-23]. In this integral ecosystem management framework, water is considered as the fundamental connection between human development and nature, the one that includes complex interrelation of physical factors with the flora-fauna that it supports; and that means, all hydrological resources (natural resources associated with water), including anthropogenic factors related to its transformation. Despite positive effect on environmental preservation, this approach has faced many difficulties in its application [5], related with political, administrative, cultural and educational factors [1].

In the historic perspective, it is necessary to mention the Conference on Water and Environment in Dublin, Ireland, 1992, where the approach of water as a natural resource in public use and material good, was proposed. Later, at the United Nations Conference on Environment and Development that took place in June of 1992, in Rio de Janeiro, Brazil, specific actions for action plan instrumentation were analyzed [1]; and hence was motivated the creation of Agenda 21, that is the action plan for sustainable development [24]. Also it was defined that water management must be based on integral ecosystem vision, within the territorial dimension of the basin and in the long run $[25,26]$. The Latin American Congress on Hydrographic Basin Management, in Arequipa, Peru, 2003 confirmed the relevance and urgency of the implementation of Integrated Water Resources Management (IWRM) in Latin America, where the basin was considered the fundamental space unit for ecosystem planning.

On its part, Forest Environmental Services (ES) are understood as "...a benefit in the form of biological processes and physicochemical functions that the environment (ecosystems) provides to living forms, in particular, to mankind" [27]. By the official definition, the ES are "...all benefits that people receive from ecosystems, including provision services (food and water), regulation services (of weather, water, health), cultural services (spiritual, aesthetic, recreational)" [28]. Thus the ES can be divided into provision services that are involved in soil formation, bio-geochemical cycles, primary production and that include: I) supply services (food, water, fuel, fibers); II) regulation (climate regulation, disease control, water regulation); III) cultural (spiritual and religious, recreation and ecotourism, aesthetic); and IV) essential services (indispensable to support the other all).

There are more recognized types of these: Carbon Capture (oxygen generation, damping of the impact of the natural phenomena, modulation or climatic regulation); Biodiversity and Landscaping (protection of biodiversity and ecosystems, land preservation and recovery, landscaping beauty and recreation); and Hydrological Environmental Services (maintenance of aquifers recharge capacity and of hydrological cycle in general, water purification, reduction of sediments flow down, reduction of the risk of floods, etc.) [12]. The last one is of the principal interest for this study.

As in the case of IWRM, the United Nations Conference on Environment and Development of 1992, took an important place in the adopting process of the Environmental Services concept where it was introduced the topic of the ES. Later, in 1997 the Kyoto Protocol, within the United Nations Framework Convention on Climate Change, planted the mechanisms of payment for ES that open the way for creation of the Carbon Capture market, as a flexible compensation public policy instrument at world scale. The central idea of the scheme of the Payment for forest Environmental Services is based on the environmental, economic and social justice, where the part of society that enjoys the benefits of the Environmental Services pays to the 
landowners that contribute to produce these benefits and for their conservation. According to [7], the Mexican federal program of Payment for Environmental Services (PES) was created in 2003 exactly in the Hydrological modality that had the purpose to recognize the environmental, social and economic value of forest's ES and to incite the paying mechanisms for them (within the catchments territory unit). Finally, it is important to mention that The Johannesburg Declaration on Sustainable Development in 2002 introduced the objective of reduction of poverty in the PES schemes; that are reflected on the integrated perspectives of the programs.

Nowadays a great number of international publications on the subject of Environmental Services (ES) exist, as scientific articles, work documents, works of popular science, protocols, technical evaluation reports, etc., with development of different study areas and where Costa Rica, USA, Brazil and China are featured. Nevertheless, at the national level of Mexico, there are few scientific papers published on the subject of ES; the majority of them are work documents and technical reports with clear economic approach dominance and absence of interdisciplinary and natural science lines [16, 29-34], see Table 1.

Additionally, we can say that the analysis of publications highlight the obvious lack of development of many topics, particularly on the understanding, conceptual and methodological definition of ES and of this physical and biological functioning (capture, transfer and discharge of surface and underground water under the concept of hydrological cycle; as well as ecosystems associated with this process). Also it is notable the absence of studies of demand determination that could establish self-sufficient local markets, where the water flows are determined and quantified. Thus, the challenge to be dealt with is highly relevant, and intends to contribute to a conceptual discussion of combining two theoretical frameworks (IWRM and PES), in the practical context of applying public environmental policy instruments. To specify this work we proposed the case study of Mexico City within the integrated perspective for analysis.

\section{CASE STUDY}

Mexico City with its Metropolitan Area has a very complex combination of geographical, economical and political issues. Now nearly 20 million inhabitants live on five thousand square $\mathrm{km}$ of the closed basin named Valley of Mexico (Fig. 1). Since its foundation, the city has had many serious problems in providing potable water to its inhabitants and disposal of sewage water. In the last century, Mexico City has expanded considerably and now 16 delegations of the Federal District and about 54 municipalities of the State of Mexico are occupied. This situation has caused the exponentially growth of the water demand, in direct proportion to the population increase, that on the other hand has produced strong pressure on the water resources at the regional level [35].

In particular, average potable water availability per capita in 2007 was about $143 \mathrm{~m}^{3} /$ inhabitants/year; and based on the forecast for 2030 with the actual use dynamic, it will be decreased to $127 \mathrm{~m}^{3} /$ inhabitants/year. This indicator is a sign of alarm, because internationally it is determined that a level below $1,000 \mathrm{~m}^{3} /$ inhabitants/year means low water availability and this reflects the crisis and a shortage of water [36].

It is necessary to comment that nearly 70 percent of all water resources that the Metropolitan Area uses to supply are from internal underground sources (Table 2). This fact underlines the importance of the conservation of natural function of internal Hydrological Environmental Services [37], that are provided by the forests higher parts of the Valley of Mexico situated in the majority at the south and south-west part of the Federal District; denominated as Conservation Land, CL (Fig. 1). As it was shown by Cram et al. [38], the morphological and edaphological characteristics of CL permit the important recharge of precipitation and, with it, the constant input of fresh water to the local aquifer that provides the major part of the potable water to the population of Mexico City [10].

The mayor problem that $\mathrm{CL}$ is facing is the urban expansion of Mexico City; that intensifies the loss of forest and other type of vegetation on CL, and causes degradation of ecosystems accompanied by disappearance of ES. During the past four decades, for example, about $30 \%$ of forest decreased in the metropolitan zone and native populations of wild flora and fauna declined to critical levels [37, 39]. In response to this situation, which is no different from the national problematic, the National Forest Commission (CONAFOR in Spanish's abbreviation) implemented the different federal programs for forest conservation with one of them based in the scheme of payment for conservation of forest environmental services.

On the other hand, it is possible to comment that within the hydric policy, the government of Mexico City constantly has resolved the problems of the supply of potable water by technocratic actions at short terms, resulting actually highly inefficient in all aspects (physical and economic condition, social conflicts and environmental impact). This way, the implementation of Integrated Water Resource Management principles, with the ecological vision of use, management and distribution of the water at large scale inside the basin, is necessary [35, 40].

\section{METHODOLOGY}

The methodology applied in this study was based on the development of four stages. On the first part we helped in the document analysis of the scientific papers, the accessible data bases and other public and official material in the order to construct the theoretical frame, with the consideration of principal concepts as IWRM and PES. On other hand, it was reviewed the implementation process of the Hydrological PES program in Mexico at national and at the local level; with case study of Conservation Land of Mexico City.

After that, the regional hydrological function of the PHES program in the Conservation Land was developed and justified with the hydrogeological profiles adopted from the technical inform of [29], based on the theory of Groundwater Flow System of Toth [41] and results of the field work performed within that investigation in 2004; that has been updated by Peñuela in 2007 [42]. 
Table 1. Scientific papers published and reviewed on the subject of PES*

\begin{tabular}{|c|c|c|c|}
\hline \multirow{2}{*}{ Scale } & \multicolumn{3}{|c|}{ Focus } \\
\hline & Natural Sciences & Socio-Economic & Interdisciplinary \\
\hline International & $\begin{array}{l}\text { - Costanza et al. (1997) } \\
\text { - Fisher and Turner (2008) } \\
\text { - Low et al. (1999) } \\
\text { - Naidoo and Ricketts (2006) } \\
\text { - Naidoo et al. (2008) } \\
\text { - Postel and Thompson Jr. (2005) } \\
\text { - Rogers et al. (2010) } \\
\text { - Wallace (2007) }\end{array}$ & $\begin{array}{l}\text { - Costanza }(2000) \\
\text { - Fisher et al. }(2009) \\
\text { - Kemkes et al. }(2010) \\
\text { - Kerr (2002) } \\
\text { - Kontogianni et al. }(2010) \\
\text { - Turner and Daily }(2008) \\
\text { - Vatn (2010) }\end{array}$ & $\begin{array}{l}\text { - Crossman et al. (2010) } \\
\text { - Fisher et al. }(2010) \\
\text { - Jogo and Hassan (2010) } \\
\text { - Nelson et al. }(2009) \\
\text { - Tianhong et al. }(2010) \\
\text { - Wendland et al. }(2010) \\
\text { - Zhang and Xie (2010) }\end{array}$ \\
\hline Latin America & $\begin{array}{l}\text { - Ferraro y Kiss (2002) } \\
\text { - Luck et al. }(2009) \\
\text { - Sánchez-Azofeifa et al. (2007) } \\
\text { - Méndez et al. (2009) } \\
\text { - Wilk (2000) }\end{array}$ & $\begin{array}{l}\text { - Kosoy et al. }(2007) \\
\text { - Miranda et al. }(2003) \\
\text { - Pagiola et al. (2005) } \\
\text { - Pagiola (2008) } \\
\text { - Rosa et al. }(2004) \\
\text { - Wunder (2005) } \\
\text { - Wunder et al. }(2008)\end{array}$ & - Hack (2010) \\
\hline Mexico & - Cram et al. (2008) & $\begin{array}{l}\text { - Alix-García et al. (2008) } \\
\text { - Alix-García et al. (2010) } \\
\text { - Corbera et al. (2009) } \\
\text { - Kosoy et al. (2008) } \\
\text { - McAfee and Shapiro (2010) } \\
\text { - Merino (2005) } \\
\text { - Muñoz-Piña et al. (2008) }\end{array}$ & \\
\hline
\end{tabular}

*Table 1 references

Alix-Gracia J, de Janvry A, Sadoulet E. The role deforestation risk and calibrated compensation in designing payments for environmental services. Environ Develop Econ 2008; 13 : 375-394.

Alix-Garcia J, Shapiro E, Sims K. Forest conservation and slippage: Evidence from Mexico's national payments for ecosystem services program. USA: University of WisconsinMadison, Department of Agricultural \& Applied Economics, Staff Paper Series 2010; 548: 1-53.

Costanza R, d'Arge R, Groot R, Farberk S, Grasso M, Hannon B et al. The value of the world's ecosystem services and natural capital. Nature 1997; $387: 253-300$.

Costanza R. Social Goals and the Valuation of Ecosystem Services. Ecosystems 2000; 3: 4-10.

Corbera E., González-Soberanis E, Brown K. Institutional dimensions of Payments for Ecosystem Services: An analysis of Mexico's carbon forestry program. Ecol Econ 2009; 68(3): 743-761.

Cram S, Cotler H, Morales LM, Sommer I. Identificación de los servicios ambientales potenciales de los suelos en el paisaje urbano del Distrito Federal. Invest Geog 2008; 66:81104.

Crossman N, Connor J, Bray B, Summers D, Ginnivan J. Reconfiguring an irrigation landscape to improve provision of ecosystem services. Ecol Econ 2010; 69(5): 1031-1042.

Ferraro P, Kiss A. Direct payments to conserve biodiversity. Science 2002; 298: 1718-1719.

Fisher B, Turner K. Ecosystem services: Classification for valuation. Biol Cons 2008; 141(5): 1167-1169.

Fisher B, Turner RK, Morling P. Defining and classifying ecosystem services for decision making. Ecol Econ 2009; 68(3): 643-653.

Fisher B, Kulindwa K, Mwanyoka I, Turner K, Burgess N. Common pool resources management and PES: Lessons and constraints for water PES in Tanzania. Ecol Econ 2010; 69(6): 1253-1261.

Hack J. Payment schemes for hydrological ecosystem services as a political instrument for the sustainable management of natural resources and poverty reduction - a case study from Belén, Nicaragua. Adv Geosci 2010; 27: 21-27.

Jogo W, Hassan R. Balancing the use of wetlands for economic well-being and ecological security: The case of the Limpopo wetland in southern Africa. Ecol Econ 2010; 69(7): 1569-1579.

Kemkes RJ, Farley J, Koliba CJ. Determining when payments are an effective policy approach to ecosystem service provision. Ecol Econ 2010; 69(11): 2069-2074.

Kerr J. Watershed development, environmental services, and poverty alleviation in India. World Develop 2002; 30(8): 1387-1400.

Kontogianni A, Luck GW, Skourtos M. Valuing ecosystem services on the basis of service-providing units: A potential approach to address the endpoint problem and improve stated preference methods. Ecol Econ 2010; 69(7): 1479-1487.

Kosoy N, Martínez-Tuna M, Muradian R, Martínez-Alier J. Payments for environmental services in watersheds: Insights from a comparative study of three cases in Central America. Ecol Econ 2007; 61(3): 446-455.

Kosoy N, Corbera E, Brown K, Participation in payment for ecosystem services: Case studies from the Lacandon rainforest, Mexico. Geoforum 2008 ; 39 (6): $2073-2083$.

Low B, Costanza R, Ostrom E, Wilson J, Simon C. Human-ecosystem interactions: a dynamic integrated model. Ecol Econ 1999; 31: 227-242.

Luck GW, Harrington R, Harrison PA, Kremen C, Berry PM, Bugter R et al. Quantifying the Contribution of Organisms to the Provision of Ecosystem Services. BioScience 2009; 59(3): $223-235$.

McAfee K, Shapiro EN. Payment for ecosystem services in Mexico: Nature, neoliberalism, social movements and the state. An of the Asof Amer Geograph 2010; 100(3): 579-599.

McAfee K, Shapiro EN. Payment for ecosystem services in Mexico: Nature, neoliberalism, social movements and the state. Ar

Méndez V E, Shapiro EN, Gilbert GS. Cooperative management and its effects on shade tree diversity, soil properties and ecosystem services of coffee plantations in western El Salvador. Agrofor Systems 2009; 76: 111-126.

Muñoz-Piña C, Guevara A, Torres-Rojo JM, Braña J. Paying for hydrological services of Mexico's forest: Analysis, negotiations and results. Ecol Econ 2008; 65(4): 725-736.

Naidoo R, Ricketts TH. Mapping the economic costs and benefits of conservation. PLoS Biol 2006; 4(11): 1-12.

Naidoo R, Balmford A, Costanza R, Fisher B, Green RE, Lehner B, Malcolm TR, Ricketts TH. Global mapping of ecosystem services and conservation priorities. USA: Natl Acad Sci USA 2008; 105: 9495-9500.

Nelson E, Mendoza G, Regetz J, Polasky S, Tallis H, Cameron R, Cha K, Daily G, Goldstein J, Kareiva P, Lonsdorf E, Naidoo R, Ricketts T, Shaw R. Modeling multiple ecosystem services, biodiversity conservation, commodity production, and tradeoffs at landscape scales. Front Ecol Environ 2009; 7(1): 4-11.

Pagiola S, Arcenas A., Platais G. Can Payments for Environmental Services Help Reduce Poverty? An Exploration of the Issues and the Evidence to Date from Latin America. World Develop 2005; 33(2): 237-253.

Pagiola S. Payments for Environmental Services in Costa Rica. Ecol Econ 2008; 65(4): 712-724.

Postel LS, Thompson HB Jr. Watershed protection: Capturing the benefits of nature's water supply services. Nat Res Forum 2005; 29 : 98-108.

Rogers H, Glew L, Honzánk M, Hudson M. Prioritizing key biodiversity areas in Madagascar by including data on human pressure and ecosystem services. Landscape Urban Plan 2010; 96(1): 48-56.

Rosa H, Kandel S, Dimas L. Compensation for environmental services and rural communities: lessons from the Americas. Working Paper Series. USA: Political Economy Research Institute, University of Massachusetts Amherst 2004; 96:1-31.

Sánchez-Azofeifa GA, Pfaff A, Robalino JA, Boomhower JD. Costa Rica's Payment for Environmental Services Program: Intention, Implementation, and Impact. Cons Biol 2007; 21(5): 1165-1173.

Tianhong L, Wenkai L, Zhenghan Q. Variations in ecosystem service value in response to land use changes in Shenzhan. Ecol Econ 2010; 69(7): 1427-1435.

Turner RK, Daily GC. The Ecosystem Services Framework and Natural Capital Conservation. Environ Res Econ 2008; 39 : 25-35.

Vatn A. An institutional analysis of payments for environmental services. Ecol Econ 2010; 69 (6): 1245-1252.

Wallace K. Classification of ecosystem services: Problems and solutions. Biol Cons 2007; 139: 235-246.

Wendland KJ, Honzák M, Portela R, Vitale B, Rubinoff S, Randrianarisoa J. Targeting and implementing payments for ecosystem services: Opportunities for bundling biodiversity conservation with carbon and water services in Madagascar. Ecol Econ 2010; 69(11): 2093-2107.

Wilk J. Local perceptions about forests and water in two tropical catchments. GeoJournal 2000; 50: 339-347.

Wunder S. Payments for Environmental Services: Some Nuts and Bolts. USA: Center for International Forestry Research 2005 ; Occasional Paper 42.

Wunder S, Engel S, Pagiola S. Taking stock: A comparative analysis of payments for environmental services programs in developed and developing countries. Ecol Econ 2008;

65(4): 834-852.

Zhang B, Li W, Xie G. Ecosystem service research in China: Progress and perspective. Ecol Econ 2010; 69(7): 1389-1395. 


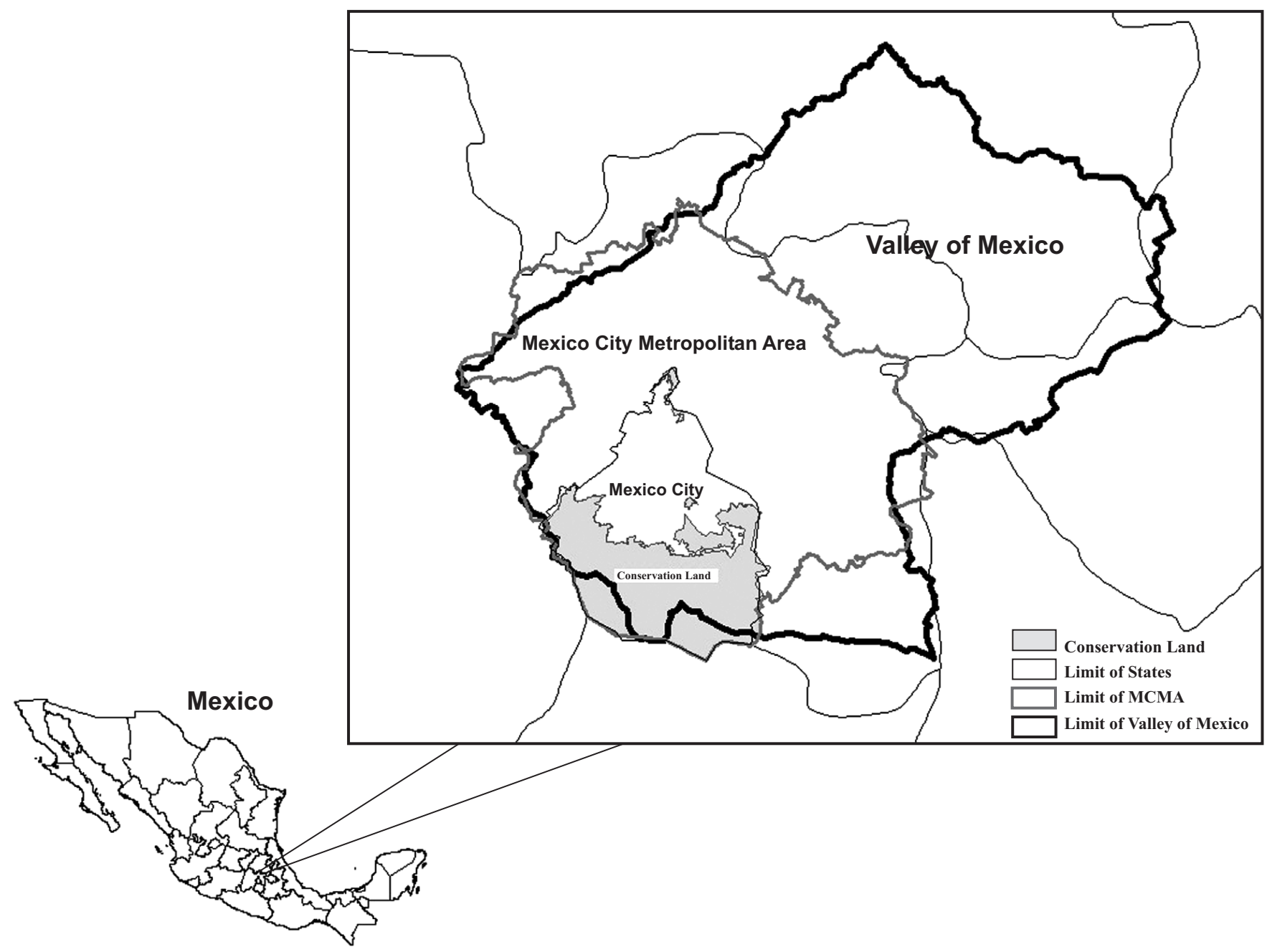

Fig. (1). Mexico City Metropolitan Area and Valley of Mexico. Source based on [40].

Table 2. Mexico City Potable Water Sources

\begin{tabular}{|c|c|c|c|}
\hline Sources & Internal & External & Total \\
\hline \multirow{2}{*}{ Underground } & Mexico Valley Basin & \multirow{2}{*}{ Lerma Basin $\left(5.1 \mathrm{~m}^{3} / \mathrm{s}\right)$} & \multirow{2}{*}{$\underline{73.50 \%}$} \\
\hline & $\left(39.7 \mathrm{~m}^{3} / \mathrm{s}\right)$ & & \\
\hline \multirow{2}{*}{ Surface } & Mexico Valley Basin & Cutzamala Basin & \multirow{2}{*}{$26.50 \%$} \\
\hline & $\left(1.1 \mathrm{~m}^{3} / \mathrm{s}\right)$ & $\left(14.7 \mathrm{~m}^{3} / \mathrm{s}\right)$ & \\
\hline Total & $67 \%$ & $33 \%$ & $100 \%$ \\
\hline
\end{tabular}

In the third part we used the methodology discussed by Ávila et al. [43]; and in this sense it was designed the strategy to carry out the application of proof interviews for decision-makers and one survey for beneficiaries of the program (that receive the payment); with the objective to know their opinions and to be able to detect the coincidence and difference in the answers. In specific, the 8 decision makers of the PES program from all institutional levels of the National Forest Commission, CONAFOR, were interviewed ( 5 from state and 3 from regional positions); and the survey was applied to the representatives of beneficiaries from 13 communities in the CL that receive the payment for hydrological modality of ES (100\% of measuring). Especially, the analysis based on the following common criteria:

a) Development and implementation of the program (diffusion, register, knowledge about objectives and operational rules, responsibility of the actors, process and principal problems)

b) Conservation effect (knowledge of environmental importance of the Conservation Land and ES that this territory offers, importance of forest conservation, monitoring and lack of studies for better understanding of ES)

c) Society effect (social cohesion, internal strong relations, environmental conscience and education, social participation in the conservation activities)

d) Economic effects (financial incomes, importance of these incomes for the family's economy, incomes' distribution in the community, productive activities, compatibility with other programs, integral forests use and benefits). 

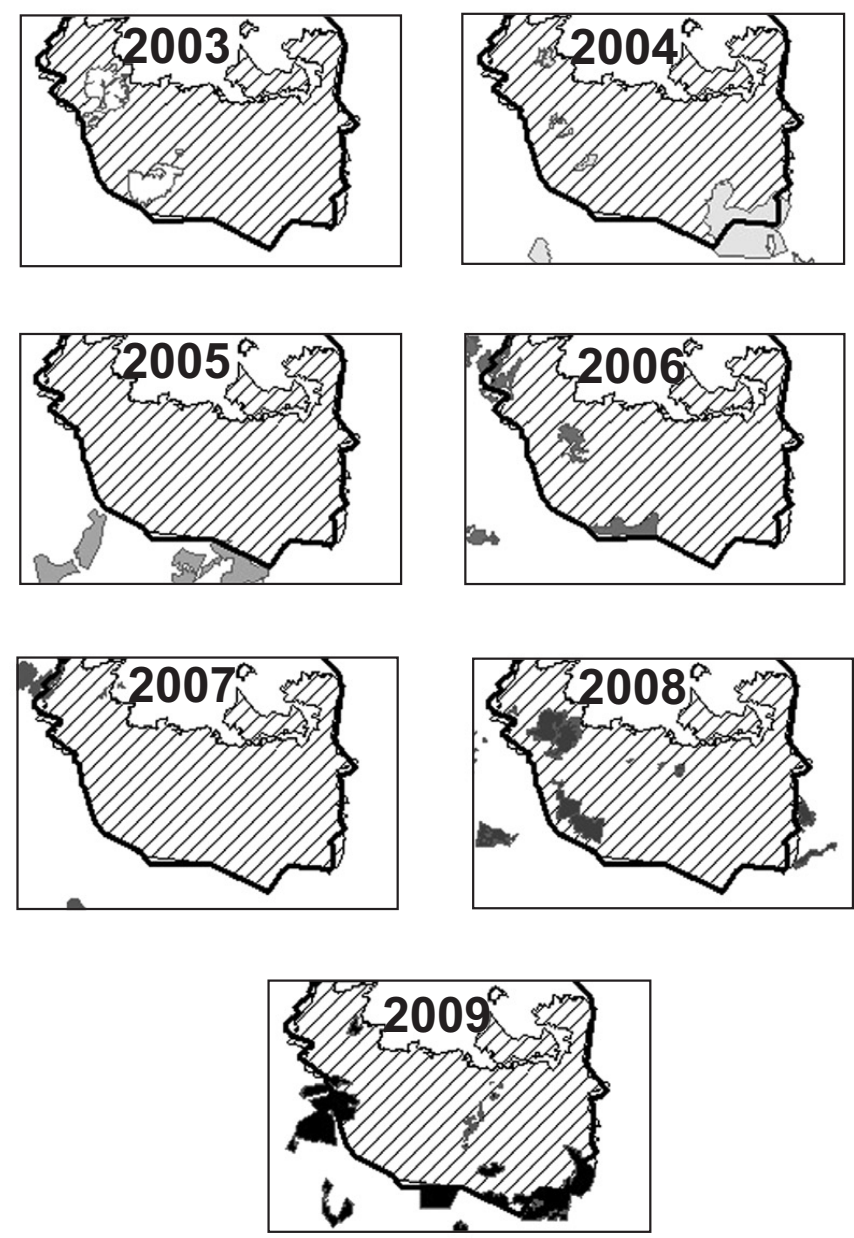

Fig. (2). Location of zones that receive the PHES on CL of Mexico City, 2003-2010. Source: based on [42].

In the final part we compare the visions of the direct participants and discuss the idea of the combination of two theoretical concepts in the implementation of one environmental program.

\section{RESULTS}

\section{General Program Dates}

The federal program of Payment for Environmental forest Services (PES) in Mexico, as an instrument of public policy, began in 2003 in Hydrological modality, following the example of Costa Rica, with two general objectives: I) reduce deforestation (related with land use change), and II) reduce poverty; carried out by CONAFOR. The modality of the PES program in the period 2003-2009 has been modified from Hydrological to the incorporation of the Carbon Capture and Biodiversity Derivatives in 2004, the project of Environmental Services of the Forest in 2005, and the articulation of four aspects within the one governing program of PROARBOL: Hydrological, Agro-forestry, Conservation of the Biodiversity, Systems and Project of Carbon Capture in 2006 (turning the last one into a separate department of the CONAFOR in 2010).

The number of the zones that receive the payment, the surface incorporated and the amount of payment demonstrate

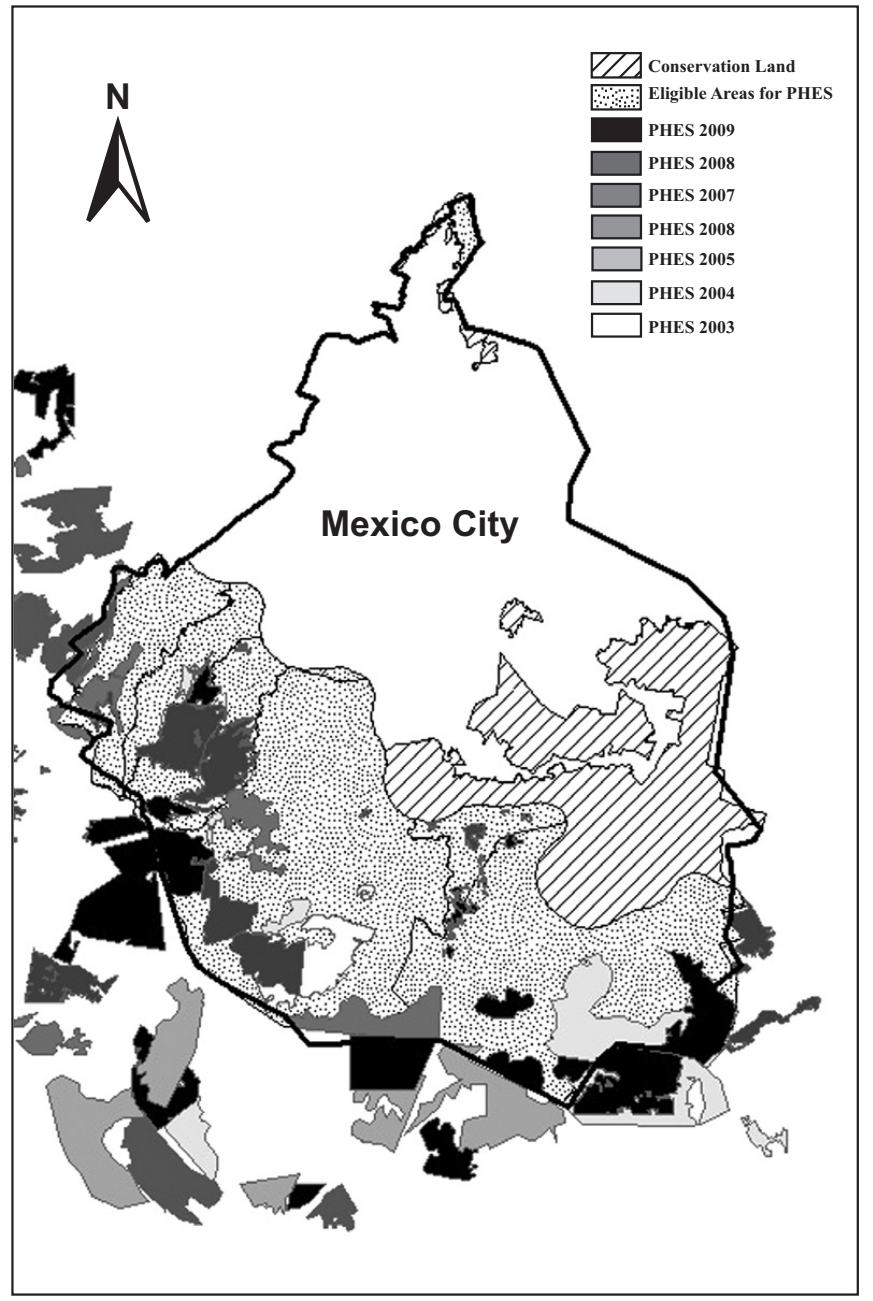

the clear growth dynamic at national level; also with the aggregation in 2008 of the amount for technical support necessary for the preparation of the Plan of Better Practice of Management [7]. It is very important to mention that since 2003 , the program objectives have changed annually and consequently the rules of operation and eligibility criteria too. Now, for example, the eligible criteria include the following aspects: location of the over-exploded aquifers, $50 \%$ of forest cover per hectare, and be the zone with high index of marginality and indigenous population, location within Natural Areas Protected and with high risk of deforestation.

In the case study of the Conservation Land of Mexico City the locations of the participating zones in the Hydrological PES program in the period 2003-2009 are represented in Fig. (2).

As it can be observed, the number of communities and ejidos that participate in the PHES program has been varying in the period 2003-2009, though always with a tendency toward increase. In general, by 2010 , there were a total of 13 zones joined at the program in this modality [44]; with incorporation of new territories through the signing of 5-year contracts. In Table $\mathbf{3}$ we can find the numbers of beneficiaries from common lands and ejidos that receive 
Table 3. Statistics of the PHES Program on CS of the Mexico City, 2003-2010

\begin{tabular}{|c|c|c|c|c|}
\hline Period of Time & Common Lands/Ejidos & Surface Receiving PHES (ha) & Expired Surface PHES (ha) & Budget of PHES \\
\hline \multirow{2}{*}{$2003-2007$} & 2 Common lands & \multirow{2}{*}{$5,057.74$} & \multirow{2}{*}{ N/A } & \multirow{2}{*}{$\$ 7,586,610$} \\
\hline & 2 Ejidos & & & \\
\hline 2004-2008 & 4 Common lands & $4,796.00$ & N/A & $\$ 7,194,000$ \\
\hline $2006-2010$ & 3 Common lands & $2,996.69$ & N/A & $\$ 4,740,084$ \\
\hline \multirow{2}{*}{$2007-2011$} & 1 Common land & \multirow{2}{*}{49.21} & \multirow{2}{*}{ N/A } & \multirow{2}{*}{$\$ 80,877$} \\
\hline & 1 Ejido & & & \\
\hline \multirow{2}{*}{$2008-2012$} & 6 Common lands & \multirow{2}{*}{$5,243.78$} & \multirow{2}{*}{$5,057.00$} & \multirow{2}{*}{$\$ 10,341,390$} \\
\hline & 2 Ejidos & & & \\
\hline \multirow{2}{*}{$2009-2013$} & 4 Common lands & \multirow{2}{*}{$5,041.91$} & \multirow{2}{*}{$4,796.00$} & \multirow{2}{*}{$\$ 9,993,162$} \\
\hline & 1 Ejido & & & \\
\hline $2010-2014$ & 2 Common lands & $3,066.83$ & 116 & $\$ 6,133,660$ \\
\hline \multirow{2}{*}{ Total } & Surfaces (ha) & $26,252.16$ & $9,969.00$ & \multirow{2}{*}{$\$ 46,069,783$} \\
\hline & Effective Surfaces (ha) & \multicolumn{2}{|c|}{$16,283.16$} & \\
\hline
\end{tabular}

payment for Hydrological ES; the incorporated surface; and the applied amount of the program during 2003-2010 [45].

According to current information, nearly 16,283 ha of forest lands have been protected in the Conservation Land of Mexico City within the period of 2003-2010; with the investment of $\$ 46,069,783$ Mexican pesos [45]. Actually the program protects $18.63 \%$ of the total area of the CL that is represented by about 87,425 ha [37]; that confirms the growing interest on the part of landowners towards the program's economic funds and possible interest on natural resources protection that influence the water and associated ecosystems quality and quantity in the Valley of Mexico. But the number is not too high due to the fact that the procedure to join the program is complicated, the payment is lower than possible incomes from other activities; local markets are not regulated; and financial resources of CONAFOR are not available to attend all received requests.

\section{Hydrological Function}

In spite of counting with enough publications on diverse hydrogeological aspects of the River basin of Mexico [29, 46-49], among others, the referring knowledge in geologic, erosion of the ground and underground hydrological operation of the high zones of the river basin are still incomplete [50]. To justify the physical function of the Hydrological ES, we were based on the hydro-geological profiles performed in the study of [29] and its update by [42], where it was demonstrated the groundwater cycle function at watershed level by the theory of [41].

In particular, to understand the groundwater flow function, its properties and manifestations, it is important to know that groundwater is the natural cause of a great variety of processes and phenomena and therefore is a geological agent of general character. As it is indicated by Toth [41], hydrogeological media is a conceptual model of climatologic, morphologic and geologic parameters that determines the flow regime in a certain place or region. The space variation of all these factors has to do with the established controls by three environmental components: the topography, the geology and the climate. Each one of them determines a part of the regime of underground water flow; for example, the climate determines the magnitude of the water presence in each region; the topography determines the distribution, movement and amount of energy of a flow system; and the geology establishes the zones where the water circulates, controlling the direction, depth and flow scheme [29].

In this way, for some PHES zones, located in the Chichinautzin and Las Cruces Mountains, it was possible to construct the hydrogeological sections and to detect the presence of local and inter-medium flow systems (Fig. 3). Where the recharge areas coincide with the Conservation Land (by the major depth of groundwater levels, high topography elevation and very high infiltration capacity) and discharge zones coincide with the plain territory of Valley of Mexico (by the brief groundwater levels and different physic-chemistry water characteristics).

By data of [48], the average speed of groundwater displacement in the zone of Chichinautzin Mountain is about $275 \mathrm{~ms}$ per year, due to its circulation in the volcanic rocks, where the hydraulic gradient is 0.0018 , hydraulic conductivity $4.22 * 10^{-5} \mathrm{~ms}^{-1}$ and porosity 0.0087 .

Especially, in the section AA", the groundwater flow is generated in the highest basin part and has the local discharges in the form of springs with low temperature $\left(14^{\circ} \mathrm{C}\right)$ and total disuses solids concentration (TDS, 90-155 $\mathrm{mgl}^{-1}$ ). In addition, it is inferred that the same zone gives rise to recharge of inter-medium flow with water temperature about $19-20^{\circ} \mathrm{C}$ and TDS of $97-306 \mathrm{mgl}^{-1}$ in the valley part [51]. For the section BB" an interpretation suggests the possibility that the Pelado Volcano is working as a recharge or transit zone that partly explains the absence of springs in 

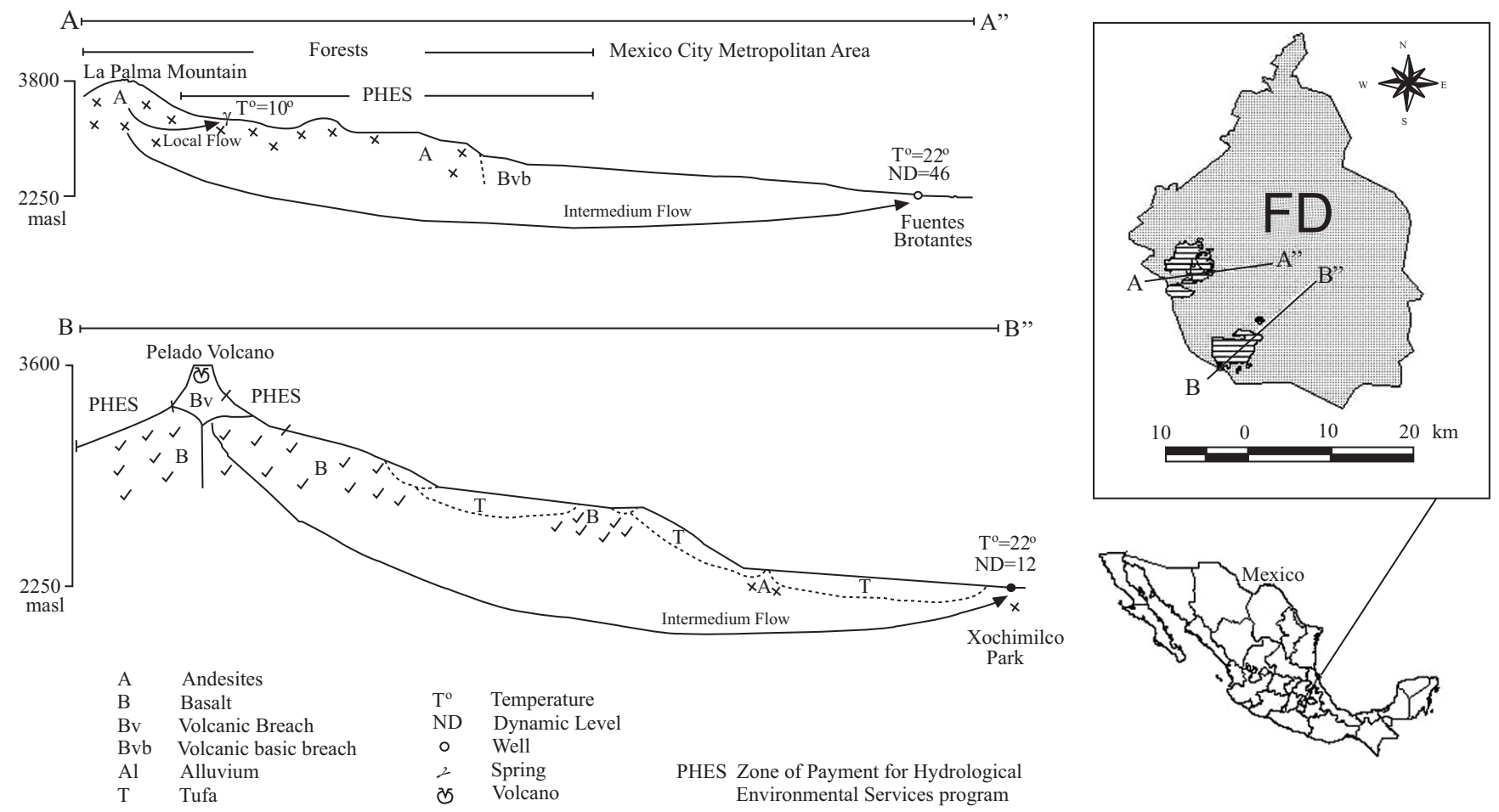

Fig. (3). Ground water flow systems in two sections of CL. Source: based on [29].

this territory. Possibly, the water that infiltrates here travels towards extraction sites in ZMCM, but by the specific hydraulic properties, it takes several hundreds to thousands of years to arrive at them [29].

By virtue of necessity and to count on the exact information on the water-forest relation, in the last years have appeared other studies, such as [52-54], where the authors performed their analysis to determine the potential of recharge zone; and two of these for the territory of Valley of Mexico. In these studies are considered the different land, vegetal surface and groundwater and climate components that nevertheless require several years of monitoring (in the high and low catchment's parts) in order to obtain their statistical significance and to be able to supply the sufficient information to evaluate the evolution of the variables in time and space.

This hydrological function renders special importance in the context of climate change. For example, in another project [40], different climate scenarios were used to forecast the impact on water availability. Despite the uncertainty of the climate change scenarios, it could be determined certain dynamics in the change of the precipitation at regional level. Especially, for the rain period, where it could be observed the increase dynamics for all scenarios and for the dry period, the drastic decrease. But, in general, by the water balance forecasts to 2050 , the supply of potable water will be reduced by 10 to $17 \%$.

In this perspective, it is necessary to change the mentality regarding towards Integrated Water Resource Management, now directed at the implementation of adaptation measures within hydrological basins. Exactly in this line the scheme of the PHES can be considered as an alternative program to the Conservation Land of Mexico City, because it pretends to conserve the vegetation cover and actual land use in the highest part of the Valley of Mexico for the benefits of the Hydrological Environmental Services.

\section{Perception of Direct Actors}

In this part of work we based ourselves on the study of Ávila et al. [43] where it was defined the general feature for analyzing the effects of different Mexican environmental public policy programs. In adopting this scheme, four groups of criteria, each one with 6-8 aspects (converted in questions) were determined, all mentioned in the Methodology part. Within this perspective, the proof structured interviews were planed and applied to 8 representatives of personnel of CONAFOR ( 5 from General Direction and ES Department at federal level and 3 from regional level).

In the case of beneficiaries, it was possible to perform one workshop with the representatives of all 13 communities of the CL that receive payment from the program in Hydrological modality, to apply a previously developed questionnaire (carrying out to obtain 31 full filled forms). The average profile of the participants could be determined as a rural man (90\% are men) of 40-60 years old, married, with about 4 members of the family and income of 2-3 minimum wages and basic education level. A relatively high degree of schooling, even higher than the average of the country, is emphasized by the nearest position to Mexico City; which additionally allows easier access to information about diverse governmental funds of environmental character.

During the process of analysis it was possible to detect some convergence and divergence points of view between the authorities and communities in referral to the PHES 
program functioning in Mexico City. In general, the decision-makers agreed that this is a good planning instrument with very high social and environmental potentials and clear application mechanism. The beneficiaries of the program are not too aware of this instrument; in particular, in the knowhow of the Operation Rules, in combination with other programs and activities to be implemented within the forest.

Following are shown the convergence points, grouping the opinions of the participants:

\section{Development and Implementation}

It is one economic support (no incentive) program at short and medium terms (5 years of contracts with the possibility to participate in the calling for other period), with clear goals, implementation mechanisms and technical support. It supposes a co-responsibility scheme between communities (by environmental conservation and proper use of money) and authorities (by offering financial support for the program and hiring of consultant service for development of Plan of Better Practice of Management, supervision of advances and technical orientation). The program potentially offers many benefits to the society, as additional economic income and environmental protection that need to be improved through education programs, academic studies and community training. But now it has insufficient infrastructure and financial funds to attend all participation requests.

\section{Conservation}

The awareness of importance of environment and forest conservation of CL (pine, oak, Mexican fir) exists. It is very recognized that $\mathrm{CL}$ offers diverse environmental services to the population of the Valley of Mexico, particularly in relation Forest-Water. Nevertheless many studies for understanding its operation are lacking. On another side, the cases of illegal felling in the last 20 years are present (for firewood, agriculture, pasture, selling timber). In general, the Hydrological PES program potentially could promote better management practices and preservation of forest's resources.

\section{Society Effect}

It potentially could generate positive effects on social organization and cohesion, also jobs and environmental awareness; however it has insufficient dissemination (diffusion) and educational programs support in schools. It should promote the voluntary participation of all community, but it really does not work in the major part of communities. The interest of the participant could be better with more and constant economical income from the program.

\section{Economy Effect}

The program generates minimal and temporary incomes for the communities. It potentially could be promoting productive diversification, but not really, because the integral forest advantage is complicated; which is only aggravated by the Forest Prohibition (Veda Forestal in Spanish). The landowners in their majority do not know the compatibility of this program with other instruments at local level, for example the one from the Commission of Natural Resources of Mexico City's Government (CORENA in Spanish abbreviation); and in general, there is a lack of knowledge about ecological benefits, social demand and economic impacts of the program. In this way, it does not promote the establishment of auto-efficient incentive schemes, because it is considered as one subsidies program and does not incorporate the local government or other organization and it is not assured as being a long upstanding period program in the long run.

The divergence points of view of the actors subdivided in the same four criteria are present in the next Table 4.

It is also very interesting to mention that there are many internal differences in the answers of authorities, for

Table 4. Divergences of the Authorities and Beneficiaries' Points of View

\begin{tabular}{|c|c|c|}
\hline Aspects & Authorities & Beneficiaries \\
\hline $\begin{array}{l}\text { Development and } \\
\text { implementation }\end{array}$ & $\begin{array}{l}\text { The objectives and Operation Roles of the PHES are clear } \\
\text { The support mechanism from CONAFOR personal is efficient } \\
\text { The population participation is ample } \\
\text { The instrument is constant with CONAFOR'S authorities changes } \\
\text { The diffusion of the program is sufficient } \\
\text { The PHES objectives have been obtained }\end{array}$ & $\begin{array}{l}\text { The knowledge of the objectives and Operation Roles are not } \\
\text { clear } \\
\text { The support mechanism is very complex and bureaucratic } \\
\text { The participation is reduced by lack of diffusion } \\
\text { The instrument is not guaranteed with community's authorities } \\
\text { changes } \\
\text { The diffusion is insufficient with lack of environmental } \\
\text { education } \\
\text { The PHES objectives have not been obtained }\end{array}$ \\
\hline Conservation & $\begin{array}{l}\text { The program promotes the natural resources enrichment } \\
\text { The PHES program is not viable for all ecosystems of CL }\end{array}$ & $\begin{array}{l}\text { The knowledge in this point is not clear by lack of information } \\
\text { The lack of information in this point is obvious }\end{array}$ \\
\hline Social effect & $\begin{array}{l}\text { The program generates the positive social effects and employments } \\
\text { The program promotes the social organization and participation } \\
\text { The program promotes the social equitation }\end{array}$ & $\begin{array}{l}\text { The program does not generate the clear positive social effects } \\
\text { The program does not promote the voluntary social } \\
\text { participation } \\
\text { The program does not promote the social equitation }(80 \% \text { of } \\
\text { participants are men) }\end{array}$ \\
\hline Economy effect & $\begin{array}{l}\text { The cost-beneficiary is positive } \\
\text { The incomes use is efficient }\end{array}$ & $\begin{array}{l}\text { The cost-beneficiary is positive only for the government } \\
\text { The incomes are often distributed in equitable form between } \\
\text { the community and are not used in forest activities }\end{array}$ \\
\hline
\end{tabular}


example, in the topics of infrastructure, sufficiency of economic resources, society and environment impact. This fact tells that they are not quite familiar with this instrument of public policy and that the instrument itself is imperfect. Beneficiaries in general have more doubts and coincide in the needs of more information about the physical functioning of the hydrological cycle, with lack in special training and environmental education. All of them mentioned the urgent needs to research several aspects of the program, as determination and evaluation of benefits, social organization and productive diversification. The specific observations in the divergence points are presented on Table $\mathbf{5}$.

All the mentioned dates show the important potential, not explored at $100 \%$, of a PES scheme, particularly on the Hydrological modality for the Conservation Land. Besides, there is a growing interest in the program on the part of communities that live in this territory for the economic benefit it brings, even though it is rather insubstantial, considering the high urban pressure of Mexico City, and higher opportunity costs of forest-agricultural lands and other interests involved. On the other hand, there is a growing knowledge of environmental issues and importance of Conservation Land for water protection and other ES in benefits of the population at regional level.

This scheme has motivated owners of forest lands to look for preservation and maintenance of their natural resources, in particularly springs, rivers, ecosystems, etc. But, apparently, it has not been viable to become in the incentive and promotion of the establishment of local financial mechanism of ES; due to the lack of social interest in this and the scientific understanding and communication to the society of many aspects of the program's function. In order to improve this situation, this should involve local level actors and combine the financial support from different sources in order to impel the social participation in the management of the natural resources; along with academic research support, monitoring and inter-institutional collaboration.

\section{CONCLUSIONS}

As it has been mentioned, starting from 2003, a new strategy has been developed to value environmental services that the forests have provided to the society, because this ecosystem contributes to water infiltration, carbon capture and preservation of biodiversity. The Payment for Hydrological Environmental Services (PHES) program is intended to become a scheme that compensates landowners of the higher parts of basins for contributing to the protection and increment of forest or other vegetation coverage, and at the same time, to guarantee the availability of water in sufficient amount and quality. But as different studies [5557] noted, this program could not become in a functional and auto-efficient compensatory mechanism due to the lack of available information of the involved parts and of many other directly involved aspects.

After presenting this analysis, we can conclude that in theory the program of PHES can be considered as one alternative instrument of the IWRM, because it is based on the concept of river basin (protecting the recharge zone to the benefits of conservation and preservation of hydrological cycle); and furthermore as the perfect adaptation mechanism in the context of Climate Change and the scenarios of the decrement of water availability on the regional scale.

But in practice this program is considered only as one of the federal subsidies and consequently does not promote the real social initiative, voluntary participation and reinvestment of the obtained economic incomes in the activities "for" and "inside" the forest, with lack of studies of many related points (as understanding of the physical function and diverse benefits) and with relatively low payment that does not cover the opportunity costs in this zone.

Finally, the opportunities for the development of the program in the future are: I) establishment of local markets (self-financed, based not only on CONAFOR's Forest Fund, but also on other funds with incorporation of local actors and long-term contracts); II) development of "service packages" (such as ecological tourism), adopted to the specific geographical conditions of each place and promoting the integral approach of natural resources; and III) reinvestment of economic incomes in activities "for" and "inside" the forest. And of course, an indispensable point, it is necessary to plan the federal strategy to perform the scientific studies, develop the inter-institutional collaboration, by monitoring schemes and education programs; that can help improve the environmental function understanding and application scheme of this instrument in particular.

\section{DISCUSSION}

As part of the discussion, we would like to propose the review of the possibility of transversal vision adoption at

\section{Table 5. Internal Divergences of Authorities and Beneficiaries' Points of View}

\begin{tabular}{|c|c|}
\hline Authorities & Beneficiaries \\
\hline $\begin{array}{l}\text { The infrastructure is sufficient or not (by the lack of professional personal, } \\
\text { vehicles and computers) }\end{array}$ & $\begin{array}{l}\text { The communication and understanding of Operation Roles is sufficient or } \\
\text { not }\end{array}$ \\
\hline $\begin{array}{l}\text { The economic resource for the program is sufficient or not (by impossibility } \\
\text { of satisfying all participant solicitations) }\end{array}$ & $\begin{array}{l}\text { There is no consensus in the knowledge of the permanence of the } \\
\text { program economic support; and the possibility of combination with other } \\
\text { programs or public policy instruments }\end{array}$ \\
\hline $\begin{array}{l}\text { The availability of the program for the Conservation Land or not (by the } \\
\text { complex combination in this territory of the factors, as high opportunity cost, } \\
\text { communal land properties, different interests and involucrate funds) }\end{array}$ & $\begin{array}{l}\text { It is not clear the availability of this program for CL (by lack of studies } \\
\text { and scientific data communication to the communities) }\end{array}$ \\
\hline $\begin{array}{l}\text { The economic incomes are sufficient or not (in comparison with the } \\
\text { opportunity land cost in this area) }\end{array}$ & $\begin{array}{l}\text { The lack of consensus about the amount of economic incomes that they } \\
\text { are likely OR would like to receive from the program }\end{array}$ \\
\hline The existence or not of the integral forest management & $\begin{array}{l}\text { The discussion about the possibility of the integral forest use and } \\
\text { advantages }\end{array}$ \\
\hline
\end{tabular}


operative level in order to promote the joint work at diverse political levels, within the unique focus of IWRM. For example, it could be possible to attempt to coordinate the transversal interaction of the following institutions: A) in the topic of water, the National Water Commission (CONAGUA) represented by the Basin Commissions at federal level and Operative Organisms of Potable Water and Clearing, as the Water System of Mexico City (in Spanish abbreviation SACM) at local level, and B) in the topic of environmental services, the National Forest Commission (CONAFOR) at federal level and the Commission of Natural Resources (CORENA) at local level.

\section{ACKNOWLEDGMENTS}

This paper has been written with the support of the project "Instruments of Public Environmental Policies and Urban Expansion: Cases of Payment for Environmental Services, the UMA's and FOCOMDE's in the context of urban expansion in the Mexico City's Metropolitan Area", 80848 of Basic Science 2007-1 CONACYT. Here is our special acknowledgment to Alex Fehér for proofreading this text.

\section{CONFLICT OF INTEREST}

Declared none.

\section{REFERENCES}

[1] Andrade Pérez Á. Lineamientos para la aplicación del enfoque ecosistémico a la gestión integral del recurso hídrico. Serie de manuales de educación y capacitación ambiental 8. México: PNUMA 2004.

[2] Satterhwaite D. Sustainable cities or cities that contribute to sustainable development? Urban Stud 1997; 34(10): 1667-91.

[3] Perevochtchikova M, Arrellano-Monterosas JLL. Gestión de cuencas hidrográficas: experiencias y desafíos en México y Rusia. Rev Lat de Rec Nat 2008; 4(3): 313-25.

[4] García R. Sistemas complejos: conceptos, método y fundamentación epistemológica de la investigación interdisciplinaria. España: Editorial Gedisa 2006.

[5] Hinrishen D, Robey B, Upadhyay UD. Forward blue revolution. Global Issues 1999; 4(1): 38-43. Available from: http://www.usem bassy-mexico.gov/bbf/ej/ijge0399.pdf

[6] Perevochtchikova M. La problemática del agua en México: revisión de la situación actual en una perspectiva ambiental. En: Lezama JL, Graizbord B, Coord. Medio Ambiente, Colección Los grandes problemas de México. México: COLMEX 2010; Vol IV: pp. 61-105.

[7] CONAFOR. Servicios ambientales y cambio climático. Coordinación general de producción y productividad. México: comisión nacional forestal 2010.

[8] Barton Bray D, Merino Pérez L. La experiencia de las comunidades forestales en México. Veinticinco años de silvicultura y construcción de empresas forestales comunitarias. México: INE, SEMARNAT, CCMSS 2008.

[9] Banco Mundial. El manejo del agua en territorios indígenas en México. USA: Banco Mundial, Departamento de México y Colombia/Región LAC 2007.

[10] CONAGUA. Atlas del agua en México 2009. México: Secretaría del Medio Ambiente y Recursos Naturales, Comisión Nacional del Agua 2010.

[11] CONAFOR. Desarrollo forestal sustentable on México, Avances 2001-2006. México: Comisión Nacional Forestal 2006.

[12] MEA. Ecosystems and human well-being: synthesis. USA: millennium ecosystem assessment, Island Press 2005.

[13] CONAGUA. Dialogs for water and climate change: call to action. México: Secretaría del Medio Ambiente y Recursos Naturales, Comisión Nacional del Agua 2011.

[14] Muñoz-Piña C, Guevara A, Torres-Rojo JM, Braña J. Paying for hydrological services of Mexico's forest: analysis, negotiations and results. Ecol Econ 2008; 65(4): 725-36.
[15] Pagiola S, Platais G. Forthcoming. Payments for environmental services. USA: The World Bank 2002.

[16] Pagiola S. Paying for water services in Central America: learning from Costa Rica, in selling forest environmental services. In: Pagiola S, Bishop J, Landell-Mills N, Eds. Selling forest environmental services: market-based mechanisms for conservation and development. UK: Earthscan 2002; pp. 37-64.

[17] Pagiola S. Payments for environmental services in Costa Rica. Ecol Econ 2008; 65(4): 712-24.

[18] Postel LS, Thompson HB Jr. Watershed protection: Capturing the benefits of nature's water supply services. Nat Res Forum 2005; 29: 98-108.

[19] Kosoy N, Martínez-Tuna M, Muradian R, Martínez-Alier J. Payments for environmental services in watersheds: insights from a comparative study of three cases in Central America. Ecol Econ 2007; 61(3): 446-55.

[20] Newson M. Land, water and development. UK: Routledge 1992.

[21] Bismas KA, King T. Integrated river basin management, the Latin American experience. India: Oxford Ed 2001.

[22] Hardy MJ, Kuczera G, Coombes PJ. Integrated urban water cycle management: the urban cycle model. Water Sci Technol 2005; 52(9): 1-9.

[23] Mitchell VG. Applying Integrated Urban Water Management Concepts: A Review of Australian Experience. Environ Manage 2006; 37(5): 589-605.

[24] CNUMAD. Agenda 21: Programa de Acciones para el Desarrollo. Rio de Janeiro, Brasil: Conferencia de las Naciones Unidas sobre el Medio Ambiente y el Desarrollo 1992.

[25] Cotler H, Comp. El manejo integral de cuencas en México: estudios y reflexiones para orientar la política ambiental. México: INE - SEMARNAT 2004

[26] Tortajada C, Guerrero V, Sandoval R. Hacia una gestión integral del agua en México: retos y alternativas. México. México: Miguel Ángel Porrúa 2004.

[27] Torres G. El Pago de los Servicios Ambientales y las Comunidades Indígenas, Ra Ximhai. Rev de Soc, Cult y Des Sust 2006; 2(1): 187-207.

[28] SEMARNAT. La Gestión Ambiental en México. México: Secretaría de Medio Ambiente y Recursos Naturales 2007.

[29] INE. Definición de indicadores de impacto al recurso hídrico en zonas receptoras de pago por servicios ambientales hidrológicos 2003/2004. Informe final. México: Instituto de Geografía, UNAM 2005.

[30] INE-TCCCR-CONAFOR. Pago por servicios ambientales en México: Situación actual y objetivos de futuro. Memorias del taller. México: CONAFOR 2007.

[31] Colegio de Postgraduados. Evaluación del programa de Pago de Servicios Ambientales Hidrológicos (PSAH). Ejercicio Fiscal 2004. México: COLPOS 2005.

[32] Colegio de Postgraduados. Evaluación Externa de los apoyos de los Servicios Ambientales. Ejercicio Fiscal 2007. México: COLPOS 2008.

[33] Collado J. Servicios ambientales y servicios mercantiles relacionados con el ambiente. Programa Agua, Medio Ambiente y Sociedad. Documento de trabajo 3. México: COLMEX, Gonzalo Rio Arronte, UNAM 2005.

[34] Bonfil H, Madrid L. Pago por servicios ambientales en la Cuenca de Amanalco-Valle de Bravo. Gaceta Ecol 2006; 80: 1-12.

[35] Perló Cohen M, González Reynoso AE. Guerra por el Agua en el Valle de México? Estudio sobre las relaciones hidráulicas entre el Distrito Federal y el Estado de México. 2da ed. México: PUECUNAM 2009.

[36] UNESCO. Agua para todos. Agua para la vida. Resumen Ejecutivo del Informe de las Naciones Unidas sobre el Desarrollo de los Recursos Hídricos en el Mundo. Francia: Organización de las Naciones Unidas para la Educación, la Ciencia y la Cultura 2003.

[37] SMA-GDF. Programa de Acción Climática de la Ciudad de México 2008-2012. México: Secretaría de Medio Ambiente del Gobierno del Distrito Federal 2008.

[38] Cram S, Cotler H, Morales LM, Sommer I. Identificación de los servicios ambientales potenciales de los suelos en el paisaje urbano del Distrito Federal. Inv Geog 2008; 66: 81-104.

[39] Libreros-Muñoz H. La desigualdad espacial del consumo doméstico de agua en el Distrito Federal, México. Reflexiones a partir de un análisis estadístico factorial. Documentos de trabajo. 
Serie Jóvenes Investigadores. Población, Territorio y Consumo de Agua. México: FLACSO 2004; pp. 45-70.

[40] Escolero-Fuentes OA, Martínez SE, Kralisch S, Perevochtchikova M. Vulnerabilidad de las fuentes de abastecimiento de agua potable de la Ciudad de México en el contexto de cambio climático. México: Centro Virtual de Cambio Climático, ICyTDF, ICAUNAM, IG-UNAM, COLMEX 2009.

[41] Toth J. Las aguas subterráneas como agente geológico: causas, procesos y manifestaciones. Boletín Geol y Min 2000; 111(4): 926.

[42] Peñuela L. Proceso de recarga-descarga de agua subterránea en zonas receptoras de Pago por Servicio Ambiental Hidrológico, Sierras Nevada y Las Cruces-México. Tesis de Maestría en Geografía, México: UNAM 2007.

[43] Ávila Foucat SV, Ramírez Ruiz F, Ortiz MonasterioA. Indicadores para las herramientas de conservación in situ. En: México: capacidades para la conservación y el uso sustentable de la biodiversidad. México: CONABIO, PNUD 2009; pp. 95-116.

[44] CONAFOR. Coberturas de las zonas receptoras de pago por Servicios Ambientales. México: Gerencia Regional XIII, Comisión Nacional Forestal 2010.

[45] Sandoval E. y Gutiérrez J. Servicios Ambientales, Experiencia federal en el. Distrito Federal En: Perez E, Perevochtchikova M, Ávila F.S. Coord. Hacia un manejo sustentable del Suelo de Conservación del Distrito Federal. México: Ed. MA Porrúa 2012; pp. 69-83.

[46] Durazo J, Farvolden RN. The groundwater regime of the Valley of Mexico from historic evidence and field observations. J Hydrol 1989; 112: 171-90.

[47] Vázquez-Sánchez E. Modelo conceptual hidrogeológico y características hidráulicas del acuífero en explotación en la parte meridional de la Cuenca de México. Tesis de Maestría en Geofísica. México: UACPyP, UNAM 1995.

[48] Esteller MV, Quentin E, Díaz-Delgado C. Uso de sistemas de información geográfica (SIG) para la determinación de parámetros utilizados en la construcción de mapas de vulnerabilidad de acuíferos. Rev Lat-Amer de Hidrogeol 2001; 2(1): 17-30.
[49] Carrera-Hernández JJ, Gaskin SJ. Spatio-temporal analysis of potential aquifer recharge: application to the basin of Mexico. J Hydrol 2008; 353(3-4): 228-46.

[50] Birkle P, Torrez RV, Gonzalez PE. The water balance for the Basin of Mexico and implications for future water consumption. J Hydrol 1998; 6(4): 500-17.

[51] Edmunds WM, Carrillo-Rivera JJ, Cardona A. Geochemical evolution of groundwater beneath Mexico City. J Hydrol 2002; 254:1-24.

[52] García Coll I, Martínez A, Ramírez A, Niño Cruz A, Domínguez L. La relación agua-bosque: delimitación de zonas prioritarias para pago de Servicios Ambientales Hidrológicos en la Cuenca del Río gavilanes, Coatepec, Veracruz. En: Cotler H, Comp. El manejo integral de cuencas en México. Estudios y reflexiones para orientar la política ambiental. México: INE, SEMARNAT 2004; pp. 99116.

[53] Ángeles Serrano G, Delgado Campos J. Urbanización y espacios del agua subterránea: nociones geográficas para revalorar el Suelo de Conservación con base en la función del agua subterránea. En: Campusano E, Perevochtchikova M, Foucat S. Coord. Suelo de Conservación del Distrito Federal ¿hacia una gestión y manejo sustentable? Serie Estudios Urbanos. México: M.A. Porrúa: 2011; pp. $125-48$.

[54] Díaz García VM. Metodología para la localización de zonas de recarga de acuíferos en el Organismo de Cuenca Aguas del Valle de México mediante sistemas de información geográfica. Tesis de Maestría en ciencias de agua. México: IMTA 2011.

[55] Pagiola S, Agostini P, Gobbi J, de Haan C, Ibrahim M. Paying for biodiversity conservation services in agricultural landscapes. USA The World Bank 2004

[56] Pagiola S, Arcenas A, Platais G. Can payments for environmental services help reduce poverty? An exploration of the issues and the evidence to date from Latin America. World Develop 2005; 33(2): 237-53.

[57] Ochoa-Tamayo AM. Programa de Pago por Servicios Ambientales Hidrológicos en México: implementación y funcionamiento. Tesis de Maestría en Estudios Urbanos. México: COLMEX 2009.

(C) Perevochtchikova and Vázquez; Licensee Bentham Open.

This is an open access article licensed under the terms of the Creative Commons Attribution Non-Commercial License (http://creativecommons.org/licenses/by$\mathrm{nc} / 3.0 /$ ) which permits unrestricted, non-commercial use, distribution and reproduction in any medium, provided the work is properly cited. 